\title{
Mongolia's External Environment: Current Status and Future Trends of Regional and Multilateral Cooperation
}

\author{
Baatar Tsend* \\ Professor (Sc.D), Leading Research Fellow, Institute International Affairs, \\ Mongolian Academy of Sciences, Ulaanbaatar, MONGOLIA \\ baatar_ts@mas.ac.mn \\ Battogtokh Baatar** \\ Lecturer, School of International Relations and Public Administration, \\ National University of Mongolia, Ulaanbaatar, MONGOLIA \\ battbaatar@gmail.com
}

\begin{abstract}
Today, the economic globalization is staging and regional trade and economic integration is gaining strength. This trend is more accelerated from the proportion of the COVID-19 pandemic in 2020. In this context, the countries revised their foreign policies and determined their priorities for cooperation.

In this article, Author analyzes the political and economic environment of Mongolia and the main tendencies of its foreign trade and economic cooperation with other countries, including Asian and neighboring countries.
\end{abstract}

Keywords: Mongolia, external environment, multilateral cooperation

\section{One. Political and Economic Environment of Mongolia}

Since the proportion of the the Mongolia, the economy shrank by COVID-19 pandemic in 2020, 10.7\% in the first three quarter and total Mongolia's situation of international exports fell by $28 \%$. Consequently, the trade and economic cooperation has unemployment rate has risen, and poverty changed fundamentally. has increased considerably among the citizens ${ }^{1}$.

The global economic growth has slowed and many countries have shown negative economic growths. Concerning

In order to bolster the economy, the Government approved several economic

1 http://1212.mn/BookLibraryDownload.ashx?url=COVIDM+\%

Received: 10 September, 2020 Accepted: 10 October, 2020

(c) The Author(s) 2020.

https://creativecommons.org/licenses/by/4.0/ 
stimulus packages, worth over $10 \%$ of GDP, including several measures to support vulnerable groups, including cash benefits; mortgages, consumer and business loan repayments were deferred; and the mortgage rate was reduced. Currently, the deficit of state budget of Mongolia has reached a record high of MNT 4.8 trillion, which is equivalent to $12.5 \%$ of $\mathrm{GDP}^{2}$.

In this context, the governments are now taking appropriate measures to reduce dependence from foreign countries, to produce strategic and products of primary necessity inside of country and develop regional integration with its neighbors and those closest. For this moment, Mongolia is one of the few countries, which is not participating widely in regional integration and which is deeply depending from foreign markets and imports. We can say that it is great time to introduce necessary changes to the priorities of foreign policy.

There are favorable political conditions for Mongolia in Asia and with regional countries such as China, Russia, Japan, Korea. Mongolia has very good traditional relations with Asian countries and has already established comprehensive strategic partnership with China, Russia, strategic relations with Japan, India, partnership relations with Korea ${ }^{3}$.

In the global level, the development path has slowly shifted from North America ant Europe into Asia and relationships between richer countries have deteriorated due to their competition to be in charge of decreasing rate of natural resources. On the other hand, there is another global pressure to work together towards solving the global emergence such as climate change, depletion of natural resource, acquisition of science and technology, and development of green economics.

For instance, China have shifted their exported oriented policy and have started to implement their new structural adjustment policy in order to meet their growing domestic demand, to create accessible growth, and to introduce innovation in their economy. Chinese authority refers this new policy to "Chinese new normal" and it has achieved certain success. As a result of these new structural changes, China's economic structure has become similar to those of developed countries.

Due to the Western sanctions, Russia's economic growth has deteriorated and their international trade and foreign economic cooperation have started to target Asian region. Firstly, Russia have started implementing policies to develop long term raw materials and manufacturing cooperation with China, and to fundraise the required capital locally as well as substitute foreign import to local manufacturing.

The Mongolia faces higher risks and more dependency on few products due to the weak economic foundation. It is not easy to tackle this issue; therefore, it needs to have good policies. This situation has worsened because Mongolia's hasn't joined any regional integration, it established only one Economic Partnership Agreement avec

2 https://mof.gov.mn/article/entry/news-2020-09-01

3 https://ikon.mn/n/1n0v 
Japan. Also in order to develop its economy, besides concentrating on is real capacity Mongolia needs to focus on the political stability, bureaucracy, reduction of corruption, and its accessibility of financial services

Due to these external environmental factors, Mongolia has many issues to consider, such as what space it belongs to, who to ally with, who to follow, and most importantly, what regional structures, organizations and forums to join and integrate with.

\section{Two. Trade and Economic Integration in Asia and Mongolia}

The Asia is one of trade and economic integration most developed region. We know the process of integrations in Asia such as APEC, ASEAN, Shanghai cooperation organization, Eurasian economic Union. In same time, Asian countries sign many bilateral agreements like FTA and EPA.

Concerning Mongolia hasn't joined any regional integration, it established only one Economic Partnership Agreement avec Japan.

Now we are studying the possibilities for Mongolia to participate in the integration process in Asia.

APEC. APEC is a major organization that integrates economies in Asia-Pacific region and evolved closely to establish a free trade and investment zone in the region. Hence, from the summit of member economies in 2015, creating free trade zones through establishing multilateral trade system in the region have demonstrated again to be APEC's main goal and have promised to announce the progress of this target by 2020 , wich is not nealisable for this moment.

By establishing FTA in AsiaPacific region, it would mean for member economies to expand their markets, open up further possibilities for manufacturing and service sectors, develop a global value chain, and attract FDI to increase competitiveness level, so that employment and profitability would increase, and raise the quality of people's life.

In this regard, Mongolia's decision to join APEC would have positive impacts on Mongolia's society. However, Mongolia won't be granted a membership in APEC for this moment is explained in the following. The reasons are:

\section{Internal Factors of Mongolia:}

Mongolia's plan for preparation to join APEC doesn't meet APEC's standard, essentially it was mainly written about declaration. For instance, according to program 1, it says that Mongolia will maintain not more than $20 \%$ of tariffs on imported goods as held responsible by the WTO; but banking, finance, communication, transportation, energy, and investment sectors didn't receive any directions but it was written only about general terms.

APEC requires its member economies to follow certain rules such as to have good governance, improve effectiveness, have structural reforms, and its member economies are responsible for its own 
working plan to implement policies to reach those objectives. However, the government of Mongolia hasn't done anything to renew or change its policies to align itself with APEC's decisions. In other words, Mongolia set a huge goal to join APEC, but it doesn't pay careful attention on which how it reaches the goal.

There is an opposite inclination of which Mongolia's economic development trend from the APEC's requirements. For instance, APEC's side hopes to achieve balanced, accessible, qualitative economic growth; on the other hand, Mongolia's economic structure tends to become more one-sided, caught in the effects of Dutch disease, the gap between social class has increased, and the state financial situation has worsened.

Mongolia was granted the permission of participation for 5 working groups of APEC, but Mongolia didn't participate in any. However, Monpecc appears to be taking certain actions in PECC's operation.

\section{External factors:}

APEC seems to be not interested in accepting new members in the short term. From the APEC's economic summit declarations that was held in Yokohama, Japan in Nov 2015 was stated that “... Due to the development gap between member economies of APEC, it is required to bring closer their development level and strengthen its cooperation... " and APEC will continue to review the possibilities of accepting new member ${ }^{4}$. Therefore, it is understood that APEC won't accept any members until establishment of FTA in Asia-Pacific.

\section{Asia-Pacific Trade Agreement} (APTA) ${ }^{5}$. The Asian-Pacific Trade Agreement was signed in 1975 to aim to promote economic development and cooperation through the adoption of mutually beneficial trade liberalization measures among all the members of the United Nations Economic and Social Commission for Asia and the Pacific.

APTA encourages developing countries in the Asia-Pacific region to expand their markets, increase production, obtain concessional or highcost products that cannot be produced domestically, increase investment, promote trade and investment in the South, and assist in the implementation of SDG-30.

The Asia-Pacific Trade Agreement is open to all members of the United Nations Economic and Social Commission for Asian and the Pacific. Mongolia's accession to the Agreement was finalized as the $7^{\text {th }}$ member of APTA by the $42^{\text {th }}$ session of the APTA Standing Committee in 2013. The State Great Khural (parliament) of Mongolia approved Agreement on 2019 and Agreement will in force in $2021^{6}$.

The agreement aims to expand trade between developing member states, stimulate their economies, liberalize trade and promote mutually beneficial cooperation, and remove tariffs, nontariff and other barriers to trade between

4 APEC leader's Declaration, 2010,

5 Although APTA wasn't mentioned in ToR, it was important to include trade indicators as the topic of APTA was discussed in the meeting with the Ministry of Foreign Affairs.

6 https://www.legalinfo.mn/details/1215 
member countries.

The APEC stakeholders negotiated a total of four tariff tariffs and agreed to reduce customs tariffs on a total of 10,677 products, and to reduce customs tariffs on a total of 366 goods imported by Mongolia from the member countries of the agreement. In addition to customs tariffs, members agreed on nontariff arrangements, trade in services, investment, and trade facilitation.

APEC member countries account for about 70 percent of our total foreign trade turnover, about 90 percent of exports, and more than 30 percent of imports. The agreement will allow the six fastestgrowing APEC member states, with more than 2.9 billion consumers, to enjoy 5-100 percent tax breaks on a total of 10,667 items.

As Mongolia will implement the "Asia-Pacific Trade Agreement" on January 1, 2021, the Mongolian Customs is preparing to implement the Agreement on Trade in Goods and the Charter of Origin?

ASEAN. In terms of Mongolia's geopolitical and geo-economic location, it is increasingly focused on the Asia-Pacific region, including ASEAN, and has an increasingly important role to play in ASEAN and beyond. Considering it as a powerful executive body, it has been active in this direction in its foreign policy concept, but due to many internal and external factors, it has not been able to make significant progress. We may have started boldly from a distance. However, this region will undoubtedly be a priority of Mongolia's foreign policy.
Therefore, there is still a need to conduct in-depth research to expand multilateral cooperation with ASEAN's specialized agencies, member countries and partners, carefully calculate the costs, benefits and opportunities, and take the initiative to advance the current level.

The study of the rationale behind regional organizations shows that while countries in the region aim to work together to achieve security and sustainable development, they often fall under the umbrella of one of the world's great powers and pursue their own goals and interests. For example, the United States and its allies have a role to play in resolving regional issues by joining regional organizations in order to use them as part of their broader strategy to maintain their influence and position in the region. China is also using its multilateralism and interests as a tool to join regional organizations and play a leading role. From all this, it can be seen that the Asian regional organizations are a form of international order and a sub-form of competition in the activities of the superpowers. By the way, the activities of socially oriented Asian regional organizations are an important new channel for influencing regional and global issues such as inequality, transparency, and the environment based on concepts, beliefs, and multilateral partnerships. Despite this, the relationship to the decision-making level remains weak.

For the past 53 years, ASEAN has made a significant contribution to regional security and sustainable development, with the goal of creating an

7 https://www.customs.gov.mn/news/daily/latest/2347-2020-10-22-13-09-45 
environment in the region that is similar to the European Union, with the free movement of goods, services, assets and labor. became a powerful organization. The organization summarizes its goals and objectives for 2019 and develops and discusses ASEAN Vision 2040 with the participation of more than 60 scientists from ASEAN and the East Asian Research Institute (ERIA) over the next two decades. has defined its vision.

The program sets out the steps to be taken by ASEAN to become a strong economic community with political unity, economic integration and social responsibility in order to gain a stronger position in the region and the world by 2040.

It also comprehensively examines a wide range of issues, including major regional and global geo-economic and geo-political changes, the fourth industrial revolution in the digital age, its economic and social impacts, and potential risks. The program details the socio-economic diversity of the region and how to adapt to it and achieve its common security and sustainable development goals.

With the successful implementation of these goals, ASEAN will become a strong EU-style regional center by 2040, with a large economy that surpasses the European Union and is governed by the United Nations.

The East Asia Summit (EAS), based on the ASEAN + 6 mechanism, is a powerful regional multilateral cooperation forum based on ASEAN. The forum is an annual regional forum of leaders from 16 countries in Northeast
Asia, Southeast Asia and South Asia. In 2011, Russia and the United States joined to expand to 18 countries, making it one of the most powerful regional and global forums .

Asian integration and multilateral cooperation in the field of security remain very limited, but the ASEAN Regional Forum (ARF), which brings together its 27 member states, is expected to play a key role.

ASEM. The Asia-Europe Meeting (ASEM) is a unique, informal platform for dialogue and cooperation between Asia and Europe on the big challenges of a fast-changing world, such as Connectivity, trade and investment, climate change, but also broad security challenges such as counter-terrorism, migration, maritime security and cyber issues. Bringing together 53 partners from across Europe and Asia, ASEM is the main multilateral platform linking Europe and Asia with significant global weight: ASEM partners represent around $60 \%$ of global GDP, $60 \%$ of global population and $60 \%$ of global trade. ASEM main purpose is to provide a platform to foster political dialogue, strengthen economic cooperation and tackle global challenges together. In many respects, recent developments in the international landscape have increased the value of ASEM as a key building block for an open, cooperative and rules-based international system ${ }^{8}$.

The ASEM dialogue addresses political, economic and cultural issues, with the objective of strengthening the relationship between our two regions,

8 https://eeas.europa.eu/diplomatic-network/asia-europe-meeting-asem/2051/asia-europe-meeting-asem_en 
in a spirit of mutual respect and equal partnership. But ASEM is not only a high-level platform of regional relations based on multilateral and equitable partnership but also is a platform of relationship and cooperation among citizens. As of today, 14 political, 51 economic and 51 socio-cultural initiatives and programs are being implemented within the framework of ASEM ${ }^{9}$.

The ASEM Summit is a biennial meeting between the Heads of State and Government, the President of the European Council, the President of the European Commission, and the Secretary-General of the Association of Southeast Asian Nations (ASEAN).

Mongolia was successfully hosted $11^{\text {th }}$ ASEM summit in Ulaanbaatar in 2016.

Mongolia's membership in ASEM in 2008 and its close cooperation with the European Union have made a significant contribution to the socio-economic development of our country.

The Council of the European Union, at its Ministerial Meeting on 9 October 2017, decided to enter into force the 2013 Partnership and Cooperation Agreement between Mongolia and the European Union. The agreement entered into force on November 1, 2017 ${ }^{10}$.

The Partnership and Cooperation Agreement between Mongolia and the European Union, consisting of nine chapters and 65 articles, was signed on April 30, 2013 in Ulaanbaatar. The Treaty on European Union, or the Treaty of Lisbon, entered into force on 1 February 2009, the first major agreement between the EU and a non-member state in the new context of the newly established EU Foreign and Security Policy and Foreign Affairs Office. This agreement is a comprehensive partnership with nonmember countries, which is important for relations and cooperation, and covers all areas of relations.

The "Partnership and Cooperation Agreement", a key document of bilateral relations between Mongolia and the European Union, expands the scope of the partnership to include trade, economic and development assistance, agriculture, local development, energy, transport, environment and climate change. There is a legal basis for intensive development in many areas, including change, research, innovation, education, culture, health, social protection, norms and standards.

The Council of the European Union has almost halved the number of countries eligible for the GSP + scheme after 2013, but Mongolia's accession to the new GSP + by 2020 is a clear indication of the EU's strong support for the country. Discounts on 7,200 types of goods include more than 80 types of Mongolian products, including all types of garments, leather goods, furs, animal wool, cashmere, beverages, alcohol, wood products, electronics, footwear, carpets, copper and copper products, iron and steel products, and other important export products for Mongolia, including duty-free supply to the European market and a 13 percent increase in exports. While the EU's GSP + concessions have had some benefits for Mongolia's business sector, they have taken full advantage of these opportunities, such

9 https://www.asem11.mn/

10 https://ec.europa.eu/commission/presscorner/detail/en/IP_17_4183 
as establishing a joint venture with EU member states to produce GSP + concessional products. It is necessary to introduce how, to produce products that are competitive in the European market, to meet international standards, norms and quality requirements, and to expand the range of export products. These discounts not only support Mongolia's exports, but also support investment. For example, if Russia is under an EU economic embargo, Russian businesses will be able to attract Siberian timber to Mongolia, produce a variety of wooden furniture and parquet floors in combination with South Korean finance and technology, and use Mongolian discounts to market in the EU. It speaks of the possibility of joint integration of Russia, Mongolia and the Republic of Korea.

As of 2017, more than $800 \mathrm{EU}$ companies have invested 3.8 billion euros, accounting for about 13 percent of foreign direct investment in Mongolia. Trade between Mongolia and the EU reached 500 million euros in 2018, equivalent to 8 percent of Mongolia's foreign trade, of which 100 million euros were exports and 400 million euros were imports. The European Union (EU) has agreed to support the successful entry of Mongolian goods into regional and international markets through diversification of foreign trade in the framework of the EU-TRAM project in 2018-2020, funded by 5 million euros. ${ }^{11}$

Development assistance is an important pillar of EU-Mongolia relations and supports the Government of Mongolia and Mongolian civil society organizations with the ultimate goal of strengthening sustainable development, meeting the Millennium Development Goals and reducing poverty.

\section{Three. The Mongolia Participate in Different Projects of Development in Asia}

CAREC. CAREC is regional project, financed by ADB. The program has initiated and implemented resultsbased regional projects, policies that have a significant impact on sustainable economic growth and regional prosperity. Since 2001 to 2019 , \$38.6 billion worth of CAREC-related investments have been made, covering 204 projects $^{12}$.

CAREC 2030 builds on the solid foundation of progress made under CAREC 2020, and provides the new long-term strategic framework for the CAREC Program leading to 2030. CAREC 2030 is aligned with national strategies and with the 2030 global development agenda. It is inspired by a mission to create an open and inclusive platform that connects people, policies and projects for shared and sustainable development ${ }^{13}$.

The Mongolia joined CAREC in 2003 , just as the program's vision of a seamless transport-corridor network was

$11 \mathrm{http}: / /$ tram-mn.eu/launch-event-of-eu-tram-project-trade-related-assistance-for-mongolia/

$12 \mathrm{https}: / /$ www.carecprogram.org/?page_id=31

13 https://www.adb.org/documents/carec-2030-connecting-region-sustainable-development 
taking shape. CAREC plays an integral part in Mongolia's efforts to exploit significant opportunities offered by the country's vast natural resources. For example, the program is turning barren land into a major gateway for trade by developing an international transport route connecting the Russian Federation with the PRC.

The construction of a logistics center in Zamyn-Uud, a crossing point on the PRC border, has enabled the efficient handling of growing volumes of exports, and has reduced transit bottlenecks. Modernized border-crossing points and upgraded roads are also providing economic benefits.

As of 2019, $\$ 678$ million has been invested in Mongolia through CAREC. The program is improving Mongolia's transport and trade infrastructure and policies, and is helping to make the country's economic growth more sustainable.

Stronger economic links fostered by CAREC are helping Mongolia to promote the view that better connections between neighbors and with global markets are key to unlocking the region's vast resources and human potential.

As a member of CAREC, our country is also connected to the western region of the Asian Highway via a paved road for passengers and freight. This is a great opportunity to expand trade and economic relations with Central and Central Asia, the Gulf countries, Russia's Western Siberia, and Europe. In addition, the ADB-funded Darkhan-Ulaanbaatar Central Vertical
Road is being implemented, which is important for the implementation of freight and cross-border cooperation agreements with neighbors. It is up to us how effectively and proactively we take advantage of these wonderful opportunities.

\section{Shanghai Cooperation Organization} (SCO). SCO was established in 2001 with the objective to strengthen regional cooperation between China, Kazakhstan, Kyrgyzstan, Russia and Tajikistan and Uzbekistan $^{14}$. These countries, except for Uzbekistan had been members of Shanghai Five. India and Pakistan were approved their membership in July 2015 and joined in 2016. Mongolia, Afghanistan, Belarus, Iran have observer status, Sri Lanka, Nepal, Armenia, Azerbaijan, Cambodia, Turkey have dialogue partner status, as well as ASEAN, Commonwealth of Independent States and Turkmenistan hold Guest Attendance status $^{15}$.

SCO is strengthening international relationships. The organization has established formal relations with European Union, ASEAN, Commonwealth of Independent States, Organization of Islamic Cooperation. $\mathrm{SCO}$ is also an observer of the United Nations General Assembly.

According to Chapter of the Shanghai cooperation organization, main goals of $\mathrm{SCO}$ are to strengthen mutual trust, friendship and good neighborliness between the member states, to strengthening peace, security and stability, to counteract terrorism,

14 https://en.wikipedia.org/wiki/Shanghai_Cooperation_Organisation 15 Ibid 
separatism and extremism etc. ${ }^{16}$ But today the organization is giving a priority to trade and economic cooperation.

Since 2003, SCO has been giving a priority to regional trade and economic cooperation, and established Business Council, Interbank Consortium which is necessary to facilitate economic cooperation, declared to establish SCO Development Bank and Development Fund. SCO adopted the SCO Development Strategy until $2025^{17}$, and drawing up a draft List of Activities on Further Development of Joint Projects in the SCO Framework for 2017$2021^{18}$. These documents and activities show us that SCO is moving forward to economic integration. But SCO economic integration is at comparatively low level than classic integrations that European Union, NAFTA, as well as ASEAN.

On one hand, transport and logistics cooperation is expanding in the scope of the SCO. On the other hand, Eurasia is becoming world economic center. Mongolia can't participate the regional cooperation of SCO using the observer status. Under this circumstances, if only focus on economic perspective, Mongolia need to join SCO.

Eurasian Economic Union (EEU). The Eurasian Economic Union is one of the new regional multilateral organizations. The Eurasian Economic Union, which unites Armenia, Belarus, Russia, Kazakhstan, and Kyrgyzstan, was first established in 2010 by three countries: Belarus, Russia, and Kazakhstan, which formed the Customs Union $^{19}$. They were established with the main goal of expanding the market and increasing domestic and foreign trade turnover. In the process, it expanded into a form of regional integration and became a unified economic union.

Only two Central Asian countries have joined the union. Other Central Asian states are wary that they have not yet joined. There are also reports that small producers in the union are being bankrupted by large countries for duty-free $\operatorname{goods}^{20}$. China has signed a Free Trade Agreement with the Eurasian Economic Union in 2018, but does not support tariff reductions on any products ${ }^{21}$.

The increasing bilateral trade ties between Russia and China-growing at half a billion dollars a month, and set to double to US $\$ 200$ billion by 2024-are seeing a parallel interest growing in how this trade can best be serviced. Russia and China are often in the position of supplier and consumer, especially for energy, however that is now being joined by other manufacturing, IT and new hi-tech industries on both sides. This is partially driven by China's Belt \& Road Initiative, partially driven by a need to divest from trade with the United States (Russia and China) and partially with the EU (Russia). Both are also developing new export markets within the Eurasian Economic Union. Russia's bilateral trade, mostly

\footnotetext{
16 https://www.files.ethz.ch/isn/31817/Policypaper17.pdf

17 file:///C:/Users/HP\%203330MT/Downloads/Development_strategy_of_the_SCO_until_2025.pdf

18 http://eng.sectsco.org/news/20171201/361433.html

19 https://dnn.mn/

20 www.jargaldefacto.com

21 https://www.bilaterals.org/?eaeu-china-trade-and-economic
} 
in its favor, has seen significant increases the past two years with fellow EAEU members Armenia (30\%), Belarus (10\%) Kazakhstan (21\%), and Kyrgyzstan (17\%). China, for its part, has also seen bilateral trade increases with Armenia (29\%), Belarus (35\%), Kazakhstan (48\%) and Kyrgyzstan (31\%). These are significant increases and can be expected to accelerate further -China is currently in the process of negotiating product tariffs on the Free Trade Agreement it signed in 2018, with the $\mathrm{EAEU}^{22}$.

This growth of trade requires free trade and related zones to be put in place, and especially near the borders of these countries. Goods from one another's factories and suppliers can be combined without the need for duties, VAT or other taxes, and a finished product then made ready for export. If these are destined for markets with the EAEU, no further duties will be payable (as and when China agrees details to the FTA). Alternatively, it means that products can be sourced from less expensive labor pools with the EAEU with again the ability to reduce the overall manufacturing cost and remain competitive for both domestic EAEU markets in addition to markets nearby, such as Japan and South Korea to the East, and the European Union and Europe to the West. Also Iran, Serbia and Vietnam all have FTAs with Eurasian members $^{23}$.

Cooperation between Mongolia and the Eurasian Economic Union began in 2015 with the signing of a Memorandum of Understanding. Subsequently, in 2017, it expressed its desire to conclude a "Free Trade Agreement" between Mongolia and the EAEU. In this context, joint research has begun ${ }^{24}$.

In our country, there is an opportunity to establish a FTA within certain conditions and limited rather than joining this organization.

In addition, there is no denying that China's regional and road initiatives are booming in the region and contributing to economic and social development, but some countries are "swallowing" large projects that "cannot be swallowed" by international experts, which poses political and economic risks continues to warn.

\section{"Belt and Road Initiative" of China.} Today, China is becoming one of the major players in the region, initiating large-scale projects and programs not only in the region but also around the world.

The "Belt and Road Initiative" is basically China's vision of future Eurasian regional integration, aimed at pursuing China's economic, foreign and security policy interests through a number of major projects. As a strong geopolitical and geo-economic development initiative, BRI aims to promote infrastructure, policy, trade, finance and cultural interconnection and cooperation between Eurasian countries.

Thus, China is expanding its trade and rolling up its sleeves to tell the region through "Belt and Roads Initiative." This initiative provides for the construction of 6 corridors, one of which must pass through Mongolia.

The three partite summit of Russia,

22 https://www.silkroadbriefing.com/news/2019/09/25/free-trade-zones-linking-china-russia-eurasian-economic-union/

23 https://en.wikipedia.org/wiki/Member_states_of_the_Eurasian_Economic_Union

$24 \mathrm{http}: / /$ ner.mn/p/522 
Mongolia and China decided in 2016 in Tashkent has decided to build this economic corridor between 3 countries through Mongolia ${ }^{25}$. Those Presidents also adopted in Ufa Road map of construction and listed of 32 projects to implement in this corridor.

Most big project of those listed is construction of gas pipeline from Russia to China through Mongolia. Last year, during the visited of PM of Mongolia to Russia, both side has decided to do jointly economic feasibility study of pipeline construction. Among the big projects, we can note railroad and highway, connecting 3 countries. Countries have agreed to renovate the railroad and to improve the highway in economic corridor.

The Chinese leader promised to support and cooperate in the implementation of major mega projects and programs "as long as it is good for you and not bad for us." During his visit last year, the Russian President said that he would expand cooperation based on trust in all areas. We don't know how long this "golden opportunity" will last. It is up to us, the Mongolians, to take the initiative, make efforts at all levels, earn their trust, take responsibility and work closely together.

The first step in Mongolia's political and economic integration by consolidating its position in the Asian region and reviving its comparative advantages and traditional channels of communication is through economic corridor projects and programs with its two neighbors. Whether it can be implemented will depend on the policies and activities of the Mongolian government and on us Mongolians.
In conclusion, in order for Mongolia to maintain its independent and pragmatic foreign policy on multiple pillars, and to participate in regional trade and economic integration in Asia, it needs the support, trust, interdependence and close cooperation of its third neighbor and multilateral development partners. We believe that there is a way to overcome the problems with less risk.

What could be the steps to join the integration of the two neighboring regions?

- Infrastructure, trade, regulatory policy, political stability, and integrated policy planning;

- Implement interdependent and coordinated policies for the development of border areas;

- Facilitate regional trade through common arrangements;

- Border and customs cooperation and harmonization of customs procedures;

- Integration into energy and transport infrastructure;

- Expanding the border market;

- Mutual support for regional integration;

- Increase investment;

- Expand regional multidisciplinary research;

Development of interdependent and interconnected logistic and industrial cluster centers in the region. These goals are important for participating in regional integration, promoting economic growth, improving competitiveness, and increasing the effectiveness of global interdependence. 